\title{
ETYKA KANTA W ŚWIETLE HERMENEUTYCZNEJ REFLEKSJI ETYCZNEJ
}

Ustosunkowanie się hermeneutyki do myśli Kanta szło od początku dwutorowo: $\mathrm{z}$ jednej strony powstanie i rozwój Filozofii Hermeneutycznej $^{1}$ - stanowiącej historycznie najpotężniejszy rodzaj interpretacjonizmu - wydaje się czymś nie do pomyślenia bez uwzględnienia zasadniczego impulsu płynącego od filozofii transcendentalnej Kanta, z jej interpretacją niezależnych od podmiotu przedmiotów doświadczenia $\mathrm{w}$ kierunku ich ujęcia jako konstruowanych przez podmiot zjawisk. Z drugiej jednak strony, Filozofia Hermeneutyczna już w pismach swego założyciela, Fryderyka Daniela E. Schleiermachera (1768-1834), nie mówiąc już o pionierach hermeneutycznego oglądu rzeczywistości, takich jak Herder, jawi się jako protest przeciwko puryzmowi i formalizmowi tego ujęcia rozumu, z którym mamy do czynienia u Kanta. Protest ten dotyczył głównie francuskiej wersji myśli oświeceniowej, z jej w gruncie rzeczy irracjonalną - ergo: destrukcyjną - wiarą w rozum, przeniósł się jednak, co najmniej w części, na bardziej sub-

\footnotetext{
1 Piszę tę nazwę wielkimi literami, dlatego iż uważam, że jest to pewien określony kierunek/nurt filozoficzny, a nie tylko styl filozofowania, do przedstawicieli którego zaliczyć by można każdego, kto bądź posługiwał się nazwą „hermeneutyka” (np. Foucaulta, z jego hermeneutyką Siebie), bądź kto stworzył teorię interpretacji/rozumienia, nawet gdyby należał do raczej wrogiej hermeneutyce tradycji analitycznej. Tak rozumiana Filozofia Hermeneutyczna jest pewnym niedokończonym jeszcze projektem, nad którym pracowali - z różną intensywnością oraz samoświadomością teoretyczną - także ci klasycy tego kierunku, o których traktuje poniższy tekst. Szerzej na ten temat w: A. Przyłebski, Hermeneutyczny zwrot filozofii, Poznań 2005.
} 
telne, Kantowskie rozumienie tego, czym jest oświecenie i czym jest/ powinna być ludzka rozumność. W pracach Schleiermachera znajdziemy wiele miejsc krytycznie odnoszących się do Kanta².

To samo dotyczy drugiego z twórców Filozofii Hermeneutycznej, Wilhelma Diltheya (1838-1911). Swą „krytyką rozumu historycznego”, której pierwszy projekt pojawił się w Einleitung in die Geisteswissenschaften, dziele opublikowanym w 1883 roku, Dilthey chciał nie tylko uzupełnić trzy krytyki Kantowskie. Praca ta zawiera także krytykę podstawowych założeń filozofii teoretycznej Kanta, z czystym podmiotem transcendentalnym na czele. Na jego miejsce Dilthey postulował przyjęcie za punkt wyjścia rozważań epistemologicznych człowieka z krwi i kości: historycznego badacza, osadzonego w naukowej kulturze swego czasu, badacza, na którego działania mają wpływ nie tylko akty poznawcze, ale także wolicjonalne i emocjonalne. Swym podejściem berliński filozof inaugurował hermeneutyczne myślenie o fenomenie nauki i naukowości.

Dlatego też Filozofię Hermeneutyczną, której zarodek powstał w dziełach Schleiermachera i Diltheya ${ }^{3}$, można, jak sądzę, potraktować jako krytyczną reakcję na ahistoryczną i aprioryczną filozofię Kanta, reakcję idącą w kierunku uwzględnienia tego, co historyczne (historyzacji rozumu) i dowartościowania tego, co aposterioryczne, to znaczy zdobyte na drodze (indywidualnego i gatunkowego) doświadczenia. Jest to jednak taka krytyka, która nie rezygnuje $\mathrm{z}$ podstawowej zdobyczy transcendentalizmu Kanta: z idei zapośredniczenia naszego doświadczenia rzeczywistości przez pewne "przed-doświadczeniowe okulary" - aparat kategorialny, który umożliwia nam pierwszą orientację $w$ świecie. Inaczej wyłożone zostają jedynie tu geneza oraz - w związku z tym - obowiązywanie owego członu zapośredniczającego. Bliskość Filozofii Hermeneutycznej względem myśli Kanta, zwłaszcza wobec jego późnych, antropologicznych pism, jest trudna do przeoczenia. Mimo to, stosunek najważniejszych przedstawicieli Filozofii Hermeneutycznej w XX stuleciu - mam na myśli Wilhelma Diltheya, Martina Heideggera, Hansa-Georga Gadamera i Paula Ricoeura - do teoretycznej filozofii Kanta jest bardziej niż sceptyczny. Właściwie cechuje się on odrzuceniem tej filozofii. Jednak powody tego odrzucenia są u każdego z wyżej wymienionych odmienne. Nie bardzo jest tu miejsce, by to szerzej naświetlać. Zadowolę się zatem tylko kilkoma uwagami.

2 Szerzej na ten temat w: A. Przyłębski, Etyka w świetle hermeneutyki, Warszawa 2010, s. 11-29.

${ }^{3}$ Pogląd ten podziela M. Jędraszewski; por. idem, Egzystencja i hermeneutyka. O filozofii Hermeneutycznej Paula Ricoeura, [w:] Horyzonty interpretacji. Wokót myśli Paula Ricoeura, red. A. Grzegorczyk, M. Loba, R. Koschany, Poznań 2003, s. 11. 
Dilthey krytykował z perspektyw swej filozofii życia Kantowskie ujęcie podmiotu transcendentalnego. Zarzucał mu, że ów podmiot pozbawiony jest życia właśnie, że w jego żyłach płynie nie krew, lecz jakiś rozwodniony sok. Prowadzi to do niezrozumienia procesu historycznego, którego wyjaśnienie Kant właściwie porzuca, powierzając go opiece Opatrzności ${ }^{4}$. Heidegger koncentruje się na próbie odsłonięcia ontologicznych założeń, konkretnie: rozmienia bycia, które rządzi Krytyka czystego rozumu, założeń pogłębiających „zapomnienie bycia”, cechujące nowożytną duchowość europejską5. Z kolei Gadamer krytykuje głównie estetykę Kanta, przede wszystkim za to, że „subiektywne przeżycie” umieszcza w centrum recepcji dzieła artystycznego, zapoznając jego wymiar prawdziwościowy, aletheiologiczny6.

W świetle tej rezerwy Filozofii Hermeneutycznej wobec teoretycznej filozofii Kanta czymś zaskakującym wydaje się to, że w obszarze filozofii praktycznej - głównie dotyczy to etyki, w mniejszym stopniu polityki - nawiązanie do idei twórcy Krytyki praktycznego rozumu jest zdecydowanie silniejsze. Prowadzi to do tego, że kierunek ten wnosi istotny wkład do podtrzymania żywotności myśli etycznej Kanta, do odnowienia i pielęgnowania jego duchowego dziedzictwa. W poniższym tekście chciałbym na przykładzie analizy etycznych rozważań Gadamera i Ricoeura pokazać, w jakim sensie $\mathrm{i} w$ jakiej mierze potencjalna etyka hermeneutyczna czerpie $\mathrm{z}$ tego dziedzictwa.

\section{Obecność Kanta w etycznej refleksji Gadamera}

Gadamer uchodzi, i to nie bez racji, za "heglistę", to znaczy za kogoś, kto w „odwiecznym sporze” między Kantem i Heglem opowiedziałby się raczej po stronie autora Fenomenologii $d u c h a^{7}$. Dowodzą tego nie tylko ważne publikacje, które poświecił filozofii Hegla, zawierające także próbę produktywnego przeniesienia niektórych elementów historycznego substancjalizmu Hegla do własnej teorii hermeneutycznej ${ }^{8}$. Także w Prawdzie

${ }^{4}$ Zob. I. Kant, Schriften zur Geschichtsphilosophie Stuttgart 1974.

${ }^{5}$ Zob. M. Heidegger, Kant i problem metafizyki, przeł. B. Baran, Warszawa 1989.

${ }^{6}$ Zob. H.-G. Gadamer, Prawda i metoda, przeł. B. Baran, Kraków 1993.

$7 \mathrm{O}$ tej alternatywie - „Kant albo Hegel” - pisze przekonująco Henning Ottmann w tekście Realizm polityczny Hegla, [w:] Filozofia polityczna Hegla, red. A. Przyłębski, Poznań 2007, s. 27-42.

8 Wskażmy tu, tylko tytułem przykładu, bez roszczenia do kompletności, na następujące teksty: Hegel und die antike Dialektik czy Die Idee der Hegelschen Logik. Tom 3 jego Dziet Zebranych nosi tytuł Hegel - Husserl - Heidegger. Heglowi poświecono w nim pięć tekstów. 
i metodzie, jego opus magnum, obecność Hegla trudno przeoczyć. Bardzo ważne jest dla Gadamerowskiej hermeneutyki zaczerpnięte od Hegla pojęcie Bildung (kształcenia, kształtowania czy formacji) oraz Heglowskie rozumienie doświadczenia (chodzi tu o „negatywność” prawdziwego doświadczenia, o bycie-doświadczonym, przeciwstawione bezkontekstowemu eksperymentowi).

Nie dziwi w tym kontekście zaangażowanie Gadamera w ukonstytuowanie się ważnej instytucji badającej i pielęgnującej myśl Hegla, jakim było i jest Hegel-Vereinigung (Stowarzyszenie Heglowskie) ${ }^{9}$. Hegel zajmuje jestem o tym głęboko przekonany - w ramach filozofii nowożytnej to miejsce, które w obrębie myśli greckiej zajmował Arystoteles, ulubiony - obok Platona - filozof Gadamera. Odsłaniając i akcentując znaczenie procesu historycznego dla wyłaniania się logosu (rozumu), reprezentuje je w nowoczesnej formie, nawet jeśli w epoce, w której przyszło Gadamerowi żyć, była to już forma przestarzała. To zaś zbliża się do własnego myślenia Gadamera o jawieniu się rozumności w i poprzez historię, wraz z jej zwieńczeniem, jakim jest tradycja. Czy w takim podejściu jest miejsce dla Kanta? Jak najbardziej. W mniejszym stopniu $\mathrm{w}$ odniesieniu do filozofii teoretycznej genialnego Królewianina, w której moc/władza podmiotu nad rzeczywistością zostaje, zdaniem Gadamera, przeakcentowana. Filozofia Hermeneutyczna, ujmując to bardzo skrótowo, nie podziela przekonania, że człowiek ma pierwotnie do czynienia nie z określonymi bytami: kamieniami, drzewami, domami czy krowami, lecz z własnymi przedstawieniami kamieni, drzew, domów czy krów, to znaczy z myślowymi reprezentacjami, powstającymi w wyniki działania ludzkiego umysłu (mózgu, rozumu).

Różnica pojawia się także, gdy przyjrzymy się Gadamerowskim rozważaniom nad możliwością etyki filozoficznej. Od początku jest dlań jasne, jak osobliwym - i wątpliwym zarazem - jest coś, co określa się tym mianem. Gadamer podziela Arystotelesowską krytykę etycznego intelektualizmu, reprezentowanego przez Sokratesa i Platona, podobnie jak Heglowską krytykę teorii moralnej Kanta, krytykę opartą na pierwszoplanowej roli tego, co autor Fenomenologii ducha określa mianem etyczności (Sittlichkeit), a co równie dobrze można by przełożyć jako „obyczajność”. Mimo to Gadamer nie uważa, że etyka stworzona przez Kanta jest pozbawiona wartości. Zachowuje ona w jego oczach cząstkową prawdę, wyodrębnia bowiem i analizuje istotne aspekty naszej postawy moralnej, sferę szeroko pojętego doświadczenia nacechowanego etycznie, nawet jeśli nie udaje się jej uchwycić tego obszaru fenomenalnego w całej jego pełni i złożoności.

\footnotetext{
${ }^{9}$ Nie mylić ze starszym od niego Internationale Hegel-Gesellschaft.
} 
W swym prawdopodobnie najbardziej reprezentatywnym tekście dotyczącym etyki, to jest w artykule O możliwościach etyki filozoficznej z 1963 roku, Gadamer już w tytule sygnalizuje swój sceptycyzm w stosunku do etyki filozoficznej jako pewnej formy czy też pewnej postaci wiedzy teoretycznej ${ }^{10}$. Jeśli filozof-etyk miałby być kimś podobnym do inżyniera, to znaczy posiadaczem pewnej wiedzy o sprawianiu czegoś, urzeczywistnianiu czegoś, to byłby tym samym kimś etycznie wyróżnionym $\mathrm{w}$ zestawieniu $\mathrm{z}$ innymi ludźmi. Ale wtedy musielibyśmy przyjąć, iż tak jak inżynier może ze swej wiedzy, np. o zbudowaniu mostu, skorzystać lub nie, podejmując się, lub nie, budowy mostu, tak samo filozof-etyk byłby wolny co do zastosowania swej wiedzy etycznej. A tej konsekwencji, uważa słusznie autor Prawdy i metody, przyjąć niepodobna. Ogólność wiedzy etycznej, jeśli przyjmiemy jej istnienie, musi być innego rodzaju niż ogólność wiedzy czysto teoretycznej. Oznacza to, iż etyka filozoficzna nie może być wiedzą zdystansowaną wobec życia, musi ona wyrastać na bazie moralnej praktyki ludzi, musi być w niej zakorzeniona i cały czas z nią spleciona. „Faktycznie, etyka filozoficzna wydaje się $\mathrm{w}$ obliczu takiego stanu rzeczy tkwić w nierozwiązywalnym dylemacie. Ogólność refleksji, w której z konieczności porusza się ona jako filozofia, wikła ją w problematyczność całej etyki praw. Jak ma ona oddać sprawiedliwość konkretności, która za pomocą sumienia, poczucia słuszności, pojednawczości miłości odpowiada na sytuację?"11 Gadamer dostrzega dwie drogi, na których można uchronić się przez nasuwającym się tu dylematem. Pierwszą naszkicował Arystoteles, druga jest dziełem Kanta. „Żadnej - pisze - nie wolno absolutyzować, obie bowiem oddają sprawiedliwość możliwości etyki"12.

Formalizm Kanta powołuje się wprawdzie na pojęcie prawa, jednak pojęcie prawa, jakie tu wchodzi $\mathrm{w}$ grę, to nie pojęcie prawa stosowane $\mathrm{w}$ odniesieniu do przyrody. Chodzi - jak wszyscy wiemy - o autoprawodawstwo (Selbstgesetzgebung), którego źródłem są ludzki rozum i ludzka wolność. Największa zasługa Kanta polega, zdaniem Gadamera, na tym, że filozof z Królewca wysunął znakomite argumenty przeciwko fatalizmowi przyrodniczej determinacji, która jakoby musiała obejmować także człowieka, argumenty zsyntezowane w twierdzeniu o "factum, jakim jest ludzka wolność", poprzez co dał podstawy dla etyki filozoficznej. I choć sam Kant

10 Przekład tego tekstu autorstwa A. Mergler ukazał się w zbiorze esejów Gadamera Teoria, etyka, edukacje. Eseje wybrane, Warszawa 2008. Niemiecki oryginał znajduje się tomie 4 Gesammelte Werke.

${ }^{11}$ H.-G. Gadamer, O możliwościach etyki filozoficznej, tłum. A. Mergler, [w:] idem, Teoria, etyka, edukacje. Eseje wybrane, op. cit., s. 128.

12 Ibidem. 
własną etykę oparł na bezwzględnym podporządkowaniu się imperatywowi kategorycznemu - przeciwko własnym skłonnościom, nawet jeśli są skłonnościami do czynienia dobra, przez co otworzył wrota rygoryzmowi moralnemu - był on odległy od tego, by przypisywać filozofowi-etykowi jakiś wyróżniony status pośród innych żyjących i działających ludzi. Uważał, iż sama umiejętność i potrzeba namysłu etycznego nie wynosi go ponad naiwność prostej świadomości obowiązku. Zadanie rozumu praktycznego jest skromniejsze. Polega ono na tym, by wspierać "czystość serca” (Unschuld des Herzen) w trudnych chwilach i złożonych etycznie sytuacjach. Oraz na tym, by wyprowadzać człowieka z błędnych dróg, na które bezmyślnie wkroczył. W zgodzie z taką interpretacją etyki Kanta największe osiągnięcie tej koncepcji Gadamer widzi w wypracowaniu tego, jak ukonstytuowuje się ludzka świadomość moralna. Ktoś - powiada - kto dokonuje namysłu etycznego, już wcześniej uznał istnienie czy też obowiązywanie (to znaczy istnienie biorące się z obowiązywania) jakichś nakazów etycznych. Gotowość do takiego namysłu odsłania zatem istnienie czegoś, co można określić mianem sumienia. Zadanie imperatywu kategorycznego polega, w świetle takiego ujęcia, na tym, by wyłączyć te elementy naszych decyzji etycznych, które biorą się z naszych indywidualnych skłonności i zarazem utrudniają jasne widzenie sprawy.

Takie podejście ma jednak także drugą, niekorzystną stronę: ustanowione metodycznie skontrastowanie powinności i skłonności utrudnia Kantowskiej etyce uznanie faktu rozwoju etycznego charakteru jednostek ludzkich, to znaczy wytwarzania się pewnego rodzaju skłonności, zamiłowania czy wręcz nawyku do czynienia dobra, do postępowania godnego. To właśnie dlatego Kant nie był w stanie w swej koncepcji wyczerpać fenomenu moralności i etyczności ${ }^{13}$. Dlatego jego dociekania muszą zostać uzupełnione o badania uwzględniające uwarunkowania działań etycznie pożądanych. Zadania tego podjął się Hegel, uzupełniając w swych Zasadach filozofii prawa Kantowską teorię moralności o nowatorską koncepcję etyczności. Na długo przed Heglem możliwość podobnego myślenia sygnalizował Arystoteles, którego dokonania w tej materii należy, zdaniem Gadamera, uwzględnić. U greckiego mędrca "nie istnieje żadne pojęcie wartości, lecz «cnoty» $\mathrm{i}$ «dobra»". Dzięki temu "spojrzenie Arystotelesa jest nakierowane bardziej na warunkowanie naszego moralnego istnienia, na zależność pojedynczych decyzji od ich każdorazowych praktycznych i społecznych warunków,

13 Przyjęte przez mnie rozróżnienie etyczności i moralności - odmienne od tego, które proponuje np. Ricoeur - idzie za skalą Kohlberga: etyczność dotyczyłaby 5 i 6 stadium rozwoju moralnego jednostki, zaś moralność stadiów 1-4. Por. B. Irrgang, Praktische Ethik aus hermeneutischer Sicht, Paderborn 1998, s. 184-188. 
a mniej na bezwarunkowość, która przysługuje zjawiskom etycznym". Wskutek powyższego udaje mu się "tak rozjaśnić istotę moralnej wiedzy, że w pojęciu «preferencji» ujmuje zarwano subiektywność świadomości moralnej, która ocenia przypadek konfliktu, jak i nośną substancjalność prawa i moralności, określającą jej moralną wiedzę i jej każdorazowe wybory"14.

Jak z tego widać, rdzeń akceptowalnego przez Gadamera rozwiązania zadania, jakim jego zdaniem jest etyka filozoficzna, tworzy podejście twórcy Etyki nikomachejskiej. Gigant myśli starogreckiej odsłonił i wyraził istotę wiedzy etycznej jako wiedzy praktycznej. Tym, co tę wiedzę konstytuuje, nie jest czyste myślenie, lecz praxis i ethos: panujące $\mathrm{w}$ danym społeczeństwie wzorce życia szczęśliwego i dobrego zarazem, takiego, za które warto się narażać, a nawet oddać życie. Dążenie do tego dokonuje się na drodze samokształcenia i samokształtowania, na której proste wypełnianie obowiązków ustępuje miejsca czynom etycznym, biorącym swój początek z zalet etycznych konkretnych jednostek (a nie "anonimowych praw rozumu"). Podobną drogą jak Arystoteles zdaje się kroczyć Hegel. Gadamer z takiej właśnie perspektywy postrzega obecność moralności i etyczności w ludzkim życiu. Nie znaczy to, iż nie dostrzega on, iż mogą pojawić się sytuacje (które jednak w normalnym życiu w normalnym społeczeństwie nigdy nie stają się normą), w których logos czy też mądrość ethosu (Heglowskiej „etyczności”) nie wystarcza, sytuacje, w których głęboki namysł etyczny jest czymś niezbędnym. W takich właśnie sytuacjach stosowanie kategorycznego imperatywu Kanta może okazać się czymś przydatnym, uzasadnionym i sensownym.

\section{Rehabilitacja etyki Kanta w pismach Paula Ricoeura}

Paul Ricoeur, drugi z wybitnych przedstawicieli Filozofii Hermeneutycznej w drugiej połowie XX wieku, idzie, jak się w wydaje, w swych pracach dotyczących etyki $\mathrm{w}$ dość podobnym kierunku do Hansa-Georga Gadamera. Nie powołując się nigdzie na autora Prawdy i metody i prawdopodobnie nie inspirując się jego nielicznym pracami na temat etyki, rozwija nolens volens i pogłębia jego ujęcie, proponując oparcie etyki filozoficznej na dwóch fundamentach: na eudajmonistycznej, teleologicznej etyce dobrego życia, stworzonej przez Arystotelesa, i na deontycznej etyce imperatywu kategorycznego autorstwa Immanuela Kanta.

\footnotetext{
${ }^{14}$ H.-G. Gadamer, O możliwościach..., op. cit., s. 135 (dot. wszystkich trzech fragmentów).
} 
Reprezentatywne dla tego poglądu jest fundamentalne dzieło Ricoeura z okresu późnego, zatytułowane nieco enigmatycznie $O$ sobie samym jako innym ${ }^{15}$. Francuski filozof wprowadza tam rozróżnienie miedzy etyką i moralnością, wiążąc tę pierwszą z dążeniem ludzkiego indywiduum do dobrego (godnego, szczęśliwego, udanego) życia, tę drugą zaś - z podporządkowaniem się jednostki istniejącym już zakazom i nakazom ${ }^{16}$. Wydaje się przy tym czymś zupełnie naturalnym, że także Ricoeur uznaje przewagę Arystotelesowego podejścia do kwestii etycznych nad Kantowskim. Analogicznie do Gadamera próbuje jednak włączyć do swej - jak to ujmuje - „małej ety$\mathrm{ki}^{\prime \prime 17}$ (to znaczy etyki z hermeneutycznego punktu widzenia) to, co najlepsze w etyce Kanta. Kształt i zakres tej integracji daje podstawę do twierdzenia, że pozycja etyki Kantowskiej jest $\mathrm{w}$ jego koncepcji nawet silniejsza niż w przypadku Gadamera.

Linię jego myślenia można - w dużym uproszczeniu - zrekonstruować w następujący sposób: punkt wyjścia Ricoeurowskich rozważań na temat etyki tworzy jego zmaganie się z "czystym Ja" Kanta i Husserla z jednej strony, z drugiej zaś - z głoszona przez Foucaulta tezą o śmierci podmiotu (a dalej: człowieka) ${ }^{18}$. Nawiązując do Heideggerowskich rozważań nad Sobą/Sobością (Selbst), podejmuje Ricoeur śmiałą próbę zastąpienia idei transcendentalnego - to znaczy ponadcielesnego i ponadhistorycznego - Ja ideą „Siebie” (niem. Selbst, fr. Soi), która określa mnie samego, w mej konkretności, przynależności do rodzaju ludzkiego i zarazem w jednostkowej niepowtarzalności ${ }^{19}$. Tak pojęta Sobość (pojęciowy skrót od bycia-sobą) ma charakter egzystencjalnego projektu, to znaczy może się realizować zarówno jako Sobość właściwa, autentyczna, jak i jako przeciętne, na wpół anonimowe Siebie-Się (Man-Selbst) ${ }^{20}$.

Tak pojętą Sobość francuski hermeneuta ujmuje - w odróżnieniu od Heideggera - nie $\mathrm{z}$ perspektywy wewnętrznego samo-rozumienia, samo-poczucia, lecz z perspektywy działania. To nie w tym bowiem, co o sobie myślimy, lecz w tym, co czynimy, w naszym działaniu, jesteśmy sobą naprawdę. Sama możliwość działania tworzy dla Ricoeura podstawowy warunek możliwości bycia sobą, samorealizacji. Działania zawierają więcej

${ }^{15}$ Polski przykład, dokonany przez B. Chełstowskiego, ukazał się w 2003 r. w warszawskim PWN.

16 P. Ricoeur, O sobie samym jako innym, tłum. B. Chełstowski, Warszawa 2003, s. 282.

17 Tak pisze o tym w: P. Ricouer, Refleksja dokonana. Autobiografia intelektualna, tłum. P. Bobowska-Nastarzewska, Kęty 2005, s. 50.

18 Teza ta jest pewnym (bynajmniej nieoczywistym) rozwinięciem tezy Nietzschego "der Gott ist tot” (co należałoby tłumaczyć „Bóg jest martwy”, a nie „Bóg umarł”).

${ }^{19}$ Por. P. Ricoeur, O sobie samym jako innym, op. cit., s. 5 i nast.

${ }^{20}$ Szerzej na ten temat: M. Heidegger, Bycie i czas, op. cit., s. 184 oraz 369 i nast. 
wiedzy o naszej prawdziwej istocie niż nasze - często zafałszowane przez obłudę - samooceny. Możliwość, a właściwie konieczność działania pociąga za sobą natychmiast tę konsekwencję, że mamy do czynienia z podmiotem żywym, ucieleśnionym, będącym $\mathrm{w}$ interakcji z otaczającym go światem. Musimy mieć przy tym świadomość tego, że nie tylko „mamy” ciało (niczym posłuszne nam narzędzie), lecz także że nim jesteśmy. Istnienie ludzkiego ciała, z podwójną - zewnętrzną i wewnętrzną - perspektywą jego odczuwania, podważa obowiązywanie postplatońskiego czy też postkartezjańskiego rozerwania (lub tylko rozłączności) dwóch odmiennych substancji - duszy i ciała.

Bycie-sobą nie jest przy tym, wedle francuskiego filozofa, czymś nam danym, lecz czymś nam zadanym. Jest zadaniem, którego wcale nie musimy podejmować, zadowalając się egzystowaniem w modusie Się: myśleć, co się myśli, czytać, co się czyta, czynić, co się czyni. Pojawia się tu zarówno możliwość upadku (w znaczeniu zapoznania, zagubienia-siebie, zapomnienia o sobie, jakie miał na myśli Heidegger), jak i wybudowywania, stwarzania samego siebie, odnajdywania siebie. Troska o własną Sobość ma rozmaite płaszczyzny artykulacji: płaszczyznę komunikacji (ja sam jako autor wyprowadzi skierowanych do innego/innych), płaszczyznę narracji (ja jako opowiadający o swoim życiu, wnoszący tym opowiadaniem w owo życie pewną jedność/tożsamość). Płaszczyznę najważniejszą stanowi dla Ricoeura tożsamość etyczna, etyczne-bycie-sobą. Najważniejszą formę wierności samemu sobie - czyli wytwarzania swej dynamicznej tożsamości - stanowi bowiem działanie zgodne $\mathrm{z}$ podjętymi przez siebie zobowiązaniami, oznaczające często walkę z własną wygodą, lenistwem czy tchórzostwem. To ono czyni nas w oczach innych ludzi osobą: kimś posiadającym swoistą godność. To zaś otwiera przestrzeń etycznego bycie-sobą.

Bycie-sobą $w$ postaci bycia-osobą nie jest czymś nam z góry przypisanym, przyznanym przez sam fakt urodzenia się człowiekiem. Jest, jak już wyżej napisano, czymś nam zdanym, pewnym zadaniem, które możemy podjąć lub odrzucić21 ${ }^{2}$ Jego przyjęcie wzmacnia naszą indywidualną tożsamość, jedność naszej Sobości, naszkicowaną już w naszej narracji o własnym życiu. Dla etycznej Sobości odmienność innych ludzi gra kluczową rolę. Uznanie Innego jako mego alter ego ma swe źródła nie w refleksji transcendentalnej (rozpoczynającej się - jak chce to widzieć Husserl - od urzeczowienia innej cielesności, wyposażenia jej w psychiczność podobną do mojej,

${ }^{21}$ Analogia wobec takiego ujęcia osoby, jakie proponuje Max Scheler, jest oczywista. Nie możemy jej tu jednak głębiej analizować ani rozwijać. Patrz: M. Scheler, Stanowisko człowieka w kosmosie, [w:] idem, Pisma $z$ antropologii filozoficznej $i$ socjologii wiedzy, tłum. A. Węgrzecki, Warszawa 1987, s. 43-149. 
wczucia się w nią itd.)22, lecz od doświadczenia bycia przedmiotem/ obiektem działań ze strony kogoś innego (np. w postaci cierpienia, które on nam zadaje, bólu, którego od niego doznajemy). Nie jest to zatem doświadczenie związane z własnym działaniem, lecz raczej z własną pasywnością, odbiorczością. Takie podejście Ricoeura słusznie wzmacnia znaczenie idei wzajemności, w dużym stopniu przeciwko jednostronnej etyce Emmanuela Lévinasa. To ono jest powodem tego, że w etyce Ricoeura kluczową rolę pełni tak zwana Złota Reguła.

Sens Złotej Reguły dobrze oddaje nasze ludowe przysłowie, mówiące, by nie czynić drugiemu, co nam samym niemiłe. Jej obecność skonstatować można już w Talmudzie babilońskim, w słowach Hillela, żydowskiego nauczyciela św. Pawła, który powiada: „nie czyń bliźniemu swemu, czego nie zniósłbyś, gdyby tobie zostało uczynione". Formuła ta w Ewangelii według św. Łukasza przybiera postać: „Jak chcecie, żeby ludzie wam czynili, podobnie wy im czyńcie" (Łk, 6,31). Reguła ta wprowadza coś niezwykle istotnego: normę (czy też postulat) wzajemności roszczeń etycznych. Oryginalność Ricoeurowskiej interpretacji etyki Kanta polega na tym, iż jego zdaniem - co słusznie podkreśla Elżbieta Wolicka - „Kant w gruncie rzeczy zachował w swej pietystycznej świadomości «złotą regułę» etyczną, i przeprowadzając operację deontologizacji tej zasady, miał na względzie jej upowszechnienie" 23 .

Obecność tej reguły - nawet jeśli zawoalowana - w imperatywie kategorycznym Kanta czyni jego etykę w oczach francuskiego hermeneuty bardzo interesującą i w dyskursie etycznym niepomijalną (a nawet więcej: wskazuje na istnienie pewnej „uniwersalnej antropologii” wspólnej Arystotelesowi i Kantowi, do której Ricoeur w swej fenomenologicznej hermeneutyce pragnie nawiązać) ${ }^{24}$. Umożliwia bowiem niesprzeczne i w miarę harmonijne powiązanie obu typów refleksji etycznej. Wymieniając dwie najbardziej zaawansowane koncepcje etyki filozoficznej, Ricoeur - podobnie jak Gadamer - przyznaje pierwszeństwo Arystotelesowi, uważa jednak, iż jego koncepcja etyki dobrego życia jest niepełna bez uzupełnienia jej o formalną etykę Kanta ${ }^{25}$.

22 Teorię wczucia, będącego podstawą poznawania innego człowieka jako osoby, rozwijała, jak wiadomo, asystentka Husserla, Edith Stein.

${ }^{23}$ E. Wolicka, Paula Ricoeura próba syntezy etyki teleologicznej i normatywnej teorii moralności, [w:] eadem, Rozważania wokót Kanta. Prolegomena do filozofii kultury jako krytyki władz podmiotu, Lublin 2002, s. 276.

24 Por. ibidem, s. 277. Rozwinięcie tego niezwykle interesującego wątku, prowadzącego wprost do hermeneutycznego - dialogicznego - ugruntowania antropologii, musimy przełożyć na inną okazję.

${ }^{25}$ Dystynkcja, którą tutaj wprowadza Ricoeur, zaliczając koncepcję Arystotelesa do etyki, a Kanta - do moralności, jest jego oryginalną propozycją terminologiczną. Choć jest ona w jakiejś mierze uzasadniona, to może tu zostać pominięta. Lepsze jest, moim zdaniem, dookreślenie tych koncepcji poprzez słowa "teleologiczna" i „deontologiczna". 
Aby dążenie do dobrego życia nie wyrodziło się w naiwne czy aspołeczne poszukiwanie szczęścia, musi ono zostać uzupełnione o szacunek, który okazuje się uniwersalnym normom. $Z$ kolei szacunek okazywany tym normom nie może popaść $\mathrm{w}$ pusty formalizm, to znaczy musi być stale odnoszony do ideału dobrego życia, aby zapobiec dogmatyzmowi abstrakcyjnych zasad moralnych ${ }^{26}$. Froneza (phronesis), to jest mądrość praktyczna, polega, wedle francuskiego filozofa, na umiejętności syntezy obu tych podejść. Urzeczywistnia się ona $\mathrm{w}$ osądzie moralnym, zapadającym $\mathrm{w}$ konkretnej sytuacji, będącym zawsze przeżyciem - emocjonalnym i intelektualnym pewnej mediacji między jakaś ogólną normą oraz oceną konkretnej sytuacji, odniesionym do naszego konkretnego, życiowego położenia.

Aby móc łatwiej powiązać teleologiczną etykę Arystotelesa z deontologiczną etyką Kanta, Ricoeur wskazuje na obecność "teleologicznego momentu" już w tej ostatniej. Dostrzega go przede wszystkim w drugim sformułowaniu imperatywu kategorycznego, który, jego zdaniem, stanowi klucz do właściwego zrozumienia sformułowania pierwszego, najbardziej znanego ${ }^{27}$. "Traktuj innego nie tylko jako środek, lecz także jako cel sam w sobie - szanuj go jako osobę" - to dla francuskiego hermeneuty inne sformułowanie Złotej Reguły. W połączeniu z postawą etyczną promowaną przez Arystotelesa oznaczałoby to: dane życie jest dobre tylko wtedy, gdy adekwatnie odpowiada na wezwanie pochodzące od innego, nawet jeśli odpowiedź ta byłaby odmienna $\mathrm{w}$ przypadku jakiegoś dobrze nam znanego Ty i anonimowych On/Ona/Oni. W pierwszym przypadku mielibyśmy do czynienia $\mathrm{z}$ troską o innego, w drugim - z troską o sprawiedliwość, którą powinniśmy wyświadczać naszym bliźnim, wszystkim ludziom, jako nam równym. Dzięki temu przejściu od konkretnego Ty do anonimowego Innego hermeneutyczna etyka Ricoeura umożliwia coś takiego, jak „polityka dobrego życia", to znaczy przejście z poziomu indywidualno-etycznego na poziom społeczno-etyczny. Podstawową zasadą tej etyki stanowi bowiem hasło „dobrego życia z innymi i dla innych w sprawiedliwych instytucjach" 28.

${ }^{26}$ E. Wolicka, pisząc o negatywnych aspektach deontologicznego formalizmu, wskazuje na: 1 . „usunięcie wszelkich "przyrodzonych» skłonności i pożądań ze sfery racjonalności i wolności"; 2 . "odcięcie się od względów utylitarnych i hedonicznych w sferze działalności oraz instytucji publicznych"; 3. „redukcję moralnej autonomii do dziedziny czystego rozumu praktycznego i wykluczenie «drugiego» (jako fenomenu) z obszaru «faktów rozumu»" oraz 4. niebranie pod uwage "sytuacji międzyosobowego dialogu, tak istotnej dla hermeneutycznej antropologii Ricoeura" E. Wolicka, op. cit., s. 282-283.

${ }^{27}$ Gwoli przypomnienia - owo podstawowe sformułowanie brzmi: „Postępuj tylko wedle takiej maksymy, dzięki której możesz zarazem chcieć, by stała się powszechnym prawem"; I. Kant, Uzasadnienie metafizyki moralności, tłum. M. Wartenberg, Warszawa 1984, s. 50.

${ }^{28}$ P. Ricoeur, O sobie samym jako innym, op. cit., s. 322 i nast. 


\section{Wnioski}

Podsumowując te krótkie wywody, wolno stwierdzić, iż etyka, która wyłania się w pracach XX-wiecznych twórców Filozofii Hermeneutycznej, odrzuca formalną etykę Kanta, jeśli miałaby ona być jedyną akceptowaną wersją etyki filozoficznej, swego rodzaju aktualnym do dziś ukoronowaniem filozoficznej refleksji moralnej. Najwybitniejsi przedstawiciele tego kierunku, jakimi bez wątpienia są Ricoeur i Gadamer, podejmują jednak próby wychwycenia tego, co w etyce Kanta fenomenologicznie - w sensie adekwatnego opisu fenomenu etyczności - najbardziej zasadne, i włączenia go do hermeneutycznego rozumienia etyki. Etyka imperatywu kategorycznego zachowuje swe obowiązywanie dla przypadków granicznych, dla sytuacji granicznych, można by powiedzieć, dla których ethos Arystotelesa czy Sittlichkeit Hegla nie przewidziały żadnej zadowalającej nas odpowiedzi.

W wyniku tej integracji złamany jednak zostaje intelektualizm i puryzm (wyznaczany przez tak zwaną bezinteresowność) etyki Kantowskiej na rzecz uwzględnienia - z jednej strony - społecznych, z drugiej zaś - emocjonalnych i charakterologicznych uwarunkowań etyczności. Opis naszego życia moralnego wyzbywa się dzięki temu sztuczności. Ludzie działają moralnie nie tylko dlatego, że chcą sprostać pewnemu minimum bycia-człowiekiem, ale także dlatego, że są dziedzicami pewnej duchowej tradycji, oraz dlatego, że oczekuje tego od nich społeczność, w której żyją lub w której chcieliby żyć. Działają tak jednak tylko dlatego, że są istotami obdarzonymi wolnością i rozumem i dlatego właśnie pragną dla siebie życia dobrego i godnego. Rozum jest tu pojmowany głównie jako zdolność intelektualna, która jest pomocna $\mathrm{w}$ przeprowadzeniu tych zamierzeń, nie tylko w sensie Kantowskiego imperatywu hipotetycznego (to znaczy know-how), ale także w sensie wiedzy o kulturze, w której realizujemy swe zamierzenia. $Z$ pewnością nie stanowi on jedynie zbioru apriorycznych zasad, z których dedukowanie, niezależne od doświadczenia życiowego, pozwalałoby wyprowadzić maksymy stosowne dla każdej sytuacji, przed którą możemy zostać postawieni.

Etyka filozoficzna nie jest zatem wszechmocna, nie jest gotową teorią, którą wypada tylko we właściwy sposób stosować w praktyce. Nie jest ona jednak dla klasyków hermeneutyki także całkowicie bezsilna. Staje się bowiem miejscem namysłu i debaty, która niekiedy okazuje się niezbędna. Etyka filozoficzna nie jest jednak jakąś czystą teorią more geometrico, systemem wyprowadzonym dedukcyjnie z ludzkiej rozumności, nie jest teorią, którą wystarczy tylko uważnie stosować w praktyce, jak zasady inżynierii przy budowie dróg czy mostów. Nie jest wiedzą wyprzedzającą praktykę 
życiową. Jej zawsze względne ogólności rodzą się wraz z nowymi wyzwaniami pojawiającymi się ze strony tejże praktyki. Nie jest też wiedzą, która mogłaby zastąpić życie zgodne z ethosem. Jeśli spełnia jakieś kryteria wiedzy, to jest to wiedza praktyczna, froneza. I właśnie dlatego Filozofia Hermeneutyczna utrzymuje, iż żaden filozof nie posiada niekwestionowanego autorytetu w obszarze etyczności, w sensie zasadniczej, z jego profesji płynącej przewagi nad kimś niefilozofującym, potrafiącym jednak intuicyjnie odróżniać dobro od zła i kierować się tym odróżnieniem.

Hermeneutyczne myślenie o etyce nie prowadzi do projektu jakiejś Etyki Hermeneutycznej, która byłaby „nową ofertą" na i tak nadmiernie przeładowanym "rynku usług etycznych". Nie jest to także proste przeniesienie pojęć rozumienia i interpretacji - konstytuujących ten kierunek filozoficzny - na poziom sądów etycznych. Nie chodzi zatem o tak zwaną „etykę dobrego, to znaczy rzetelnego interpretowania", mimo iż moralnym ocenom ludzkich czynów należy się próba ich pogłębionego i możliwie wszechstronnego zrozumienia. Gdyby miało to jednak skutkować tym, że mogąc wszystko zrozumieć, możemy wszystko wybaczyć, to taka etyka byłaby całkowitym nieporozumieniem. Oznaczałaby $w$ istocie paraliż moralnego osądu, a to znaczy - blokadę samej moralności. Rdzeń hermeneutycznego podejścia do etyki - podejścia, które nie kieruje się oczywistością i wiecznością istnienia moralności, lecz uwzględnia sensowność pytania: „dlaczego warto być moralnym?" - stanowi zatem nie tyle "operacja zwana rozumieniem" 29 , co świadomość znaczenia moralności w życiu wspólnotowym, zrozumienie dla wymagań ethosu, nabycie phronesis i stosowanie - gdy trzeba zreinterpretowanego hermeneutycznie imperatywu kategorycznego.

Ani Gadamer, ani Ricoeur nie budują jakiejś nowej koncepcji etycznej. Dokonują oni raczej krytycznej ewaluacji dwóch najpoważniejszych, klasycznych teorii, dochodząc do wniosku, iż logiczne i naturalne pierwszeństwo ma etyka dążenia do dobrego życia, to znaczy życia godnego, szczęśliwego i udanego. To dążenie nigdy nie przestanie być motorem napędowym kierującym istotą rozumną, jaką jest człowiek. Dobre życie, mimo że dotyczy ludzkich jednostek, jest niemożliwe bez odniesienia do bliskich i dalekich innych, a więc do społecznego kontekstu, w którym się realizuje. A ponieważ pojawia się $\mathrm{w}$ nim przemoc i niesprawiedliwość, to niezbędna jest instancja umożliwiająca krytykę tego, co jest (to znaczy bytu), w imię tego, co być powinno (pewnego ideału). Taką instancję, wprowadzającą korygującą rolę

${ }^{29}$ Mówiąc o „operacji zwanej rozumieniem”, mam na myśli oczywiście klasyczny już tekst Theodore'a Abla, wybitnego ucznia F. Znanieckiego działającego w USA, zatytułowany Operation called "Verstehen", którego hermeneutyczną dekonstrukcją zajął się Zdzisław Krasnodębski w znakomitej książce Rozumienie ludzkiego zachowania, Warszawa 1986. 
normy, Ricoeur odnajduje w rozumie praktycznym Kanta, w jego imperatywie kategorycznym. Nie następuje tu zatem niepotrzebna absolutyzacja czystości moralnych intencji, tak utrudniająca akceptację etyki Kantowskiej, lecz jej włączenie w całość, którą wyznacza myśl Arystotelesa, a kontynuuje - na swój sposób - filozofia Hegla.

Francuski hermeneuta mówi w tym kontekście o pierwszeństwie etyki teleologicznej nad deontyczną, o konieczności sprawdzania naszych dążeń do dobrego życia przy pomocy filtru, jakim jest ogólna norma, oraz do ponownego odwoływania się do tego dążenia, gdy posłuszeństwo normie zaprowadzi nas w ślepą uliczkę. „Wbrew godnej szacunku tradycji, nie mielibyśmy zatem do czynienia z sytuacją, w której Kant zastąpiłby Arystotelesa. Między dwiema spuściznami powstałby raczej stosunek zarazem podporządkowania i dopełniania się, który zostałby ostatecznie wzmocniony przez końcowe odwołanie się od moralności do etyki" 30 . Dzieje się tak dlatego, że dążenie do życia dobrego, którego pełnię gwarantuje życie z inny$\mathrm{mi}$, dla innych oraz $\mathrm{w}$ sprawiedliwych instytucjach, genetycznie (w swym "porządku założycielskim", jak to ujmuje Ricoeur) poprzedza zakaz i na$\mathrm{kaz}^{31}$. Ujmując to inaczej, powiedzieć można, iż norma jest na usługach racjonalnie uzasadnionego życzenia (dążenia, pragnienia).

\section{Ethics of Kant in Light of the Hermeneutic Reflection on Ethics}

Summary

Well known is the distance of Hermeneutical Philosophy - whose fundaments, based on the findings of Heidegger and Dilthey, were created by Gadamer and Ricoeur - to Kant's theoretical philosophy, i.e. to his theory of knowledge. This is surprising that in the area of practical philosophy - mainly applied to ethics, to a lesser extent to policy - a reference to the ideas of the author of Critique of the Practical Reason is definitely stronger. The effect of this is that Hermeneutical Philosophy makes an important contribution to maintaining the vitality of ethical thought of Kant,to renew and nurture its spiritual heritage. This text shows, due to an analysis of the ethical considerations of Gadamer and Ricoeur, in what wayand to what extent ethical reflection in hermeneutics derives from this heritage.

\footnotetext{
${ }^{30}$ P. Ricoeur, O sobie samym jako innym, op. cit., s. 283.

${ }^{31}$ P. Ricoeur, Refleksja dokonana, op. cit., s. 71.
} 